\title{
Social Innovation Model Based on Collaboration Between Government and NGOs in Covid-19 Crisis: Evidence from Iran
}

Mehrnaz Moeenian

Islamic Azad University Science and Research Branch

Abbas Khamseh ( $\nabla$ Abbas.khamseh@kiau.ac.ir)

Karaj Islamic Azad University https://orcid.org/0000-0002-1263-919X

Maziyar Ghazavi

Qazvin University: Qazvin Islamic Azad University

\section{Research Article}

Keywords: Social Innovation, Collaboration with NGOs, Social Policy, Covid-19 Crisis, Qualitative Approach

Posted Date: August 26th, 2021

DOI: https://doi.org/10.21203/rs.3.rs-835817/v1

License: () (i) This work is licensed under a Creative Commons Attribution 4.0 International License. Read Full License 


\section{Abstract}

Background: Timely information and risk assessment in crises, can save people's lives at risk in emergencies, providing effective, prompt, and coordinated interventions. In this context, the best and most effective way to attract social collaboration is through the combination of different ideas and forms of cooperation and creating a new approach to a social issue called social innovation. The present study seeks to identify the dimensions of social innovation based on the collaboration between government and NGOs in crises.

Methods: This study is applied research in terms of purpose and qualitative research in terms of method, in which the Grounded Theory strategy has been used. The statistical population of the study is health experts from the Ministry of Health and Medical Education of Iran. Exploratory analysis and MAXQDA 2020 software were used to identify the components of the model. By selecting and reviewing 68 research in-depth, the initial framework was prepared. Then, through a semi-structured interview with experts, the framework was adapted and reviewed.

Results: Based on the analysis of the collected data, 39 open codes were extracted and the components of the social innovation model are identified as follows: the effectiveness of NGOs collaboration, as axial phenomenon; investment, to attract NGOs collaboration, as casual conditions; ability to manage the implementation of the social innovation plan and ability to network, as strategies; ability to policymaking overall social innovation plan and providing the necessary cultural and educational infrastructure, as contextual conditions; the existence of capable legal organizations to solve the executive problems of the plan and facilitate coordination, as intervening conditions and controlling, containing and reducing the effects of the crisis, as consequences.

Conclusion: The research results, give policymakers a model for social innovation by involving NGOs, especially in times of crisis. Also, they can be used in government planning for social development.

\section{Introduction}

Innovation is a necessity of civilization. The new circle of world development in the present age is witnessing a wide competition based on innovation to access scarce and limited resources that guarantee the path of long-term and sustainable growth of society. Applying the word innovation to a phenomenon requires that its occurrence cause markedly significant qualitative changes. There are different types of innovations, including technological, economic, business, etc., which are influential in responding to the needs and creating human well-being. However, many needs have not been met. From the point of view of various experts, one of the ways to meet the needs is a kind of dynamic innovation in all areas called social innovation [1][2][3][4][5]. Social innovation is a social goal related to improving the lives of individuals and society to achieve satisfaction through a better, more efficient, effective, fairer, and more sustainable response to existing, new, and especially unmet needs [6]. Social innovation is a new issue which states, that people are always trying to find new solutions to social needs. Hence, part of the appeal of social innovation stems from the fact that it can be used as an "umbrella" to solve social challenges creatively and positively. In other words, social innovations are innovations that are social, both in their means and in their goals, and seek to find new answers to social problems and challenges by identifying and providing new services that improve the lives of people in society [7]. Given the points and concepts that have been made, the importance of social innovation in a crisis is much more tangible and understandable. in particular a pandemic like Covid 19, which is causing a crisis in the whole world. And, the fact that a pre-arranged tool or formula for controlling such a crisis isn't in hand. The purpose of this study is initially identifying the factors and indicators affecting social innovation based on the collaboration between government and NGOs in crises especially in the field of health. The importance of the issue stems from the fact that in a pandemic such as the Covid epidemic, due to the extent, obscurity, and speed of the crisis, the responsible institutions alone cannot succeed in controlling the crisis without the collaboration between government and NGOs. The collaboration between government and NGOs is the process of using the individual or group capabilities of stakeholders to achieve a group goal. In this process, conscious behavior, collective desire, collective acceptance, choice, and shared needs are essential. What is important in a successful collaboration process is the feeling of need to solve a problem, recognizing that problem, and feeling the need for group cooperation according to the amount of knowledge and ability of individuals and their understanding of existing skills and facilities and their maximum use. The novelty of this study to its previous ones [8][9][10][11][12][13] [14][15][16][17][18][3][19][20] in essence, it examines the collaboration between government and NGOs in creating a model of social innovation in times of crisis. In this study, the collaboration between government and NGOs is discussed in Iran, which is a developing country with a large area and a population of more than eighty million people and a great deal of cultural and ethnic diversity and is under sanctions in terms of international relations. In addition, the crisis refers to the special and unique circumstances of the Covid 19 epidemic. It is also qualitative in terms of research method, and because it uses the" Grounded Theory" strategy with an inductive approach to design the model, it is new.

The main purpose of this research is to identify the dimensions of social innovation based on the collaboration between government and NGOs in a crisis and then to explain a paradigm model for social innovation built on these dimensions and reach a theory.

\section{Theoretical Foundations}

The concept of social innovation consists of two different elements because the social element has various interpretations. Therefore, the relationship between innovation and society is a complex issue [21]. Collaborative partnerships in the field of social innovation are also increasing, with public and private companies and civil society playing a role in these collaborations [22]. This increase in participation in the community, which of course, is to meet the needs of the society, will surge empowerment and expand their scope [23]. Increasing social empowerment also leads to improving social resilience, through which society will become a social system. Social innovation can appear in all organizations and institutions of society and be an achievement for solving social problems creatively. Innovation, especially in times of crisis, requires not only collective intelligence to take effective action toward common goals but also the determination and effort to converge on different ideas as quickly as possible [24]. This convergence can help adopt agile and effective strategies for value creation, even in the current unprecedented epidemic [25]. Awareness of the dangers of a crisis at the right time, provided that prompt and effective action is taken, can be an excellent way to save people's lives at risk. This awareness has become a significant need for society in times of crisis, and therefore, the role 
of social innovation to address this need will be very important [23]. The part of social participation by creating convergence in different ideas is essential for the formation of social innovations [24]. Because participation is considered as a social, general, comprehensive, multidimensional, and multicultural process that aims to involve all people to play a role in all stages of development. Therefore, macro-policymakers must look for a way to engage civil society and NGOs in times of crisis. In this regard, the best and most effective way to attract social participation is by using and organizing the neighborhood-based volunteer forces and NGOs. Because while NGOs are part of civil society, their activities and the relationship between them, empower civil society [26]. This neighborhood-based partnership should be designed to win people's trust. Goals and activities should be designed and implemented by NGOs in an acceptable way and in line with the culture and ability of the local people. In recent decades, NGOs have expanded greatly. These organizations are voluntary groups of individuals or organizations that seek to provide public services, support public policy or build capacity for social reconstruction by being independent of governments. The main activities of NGOs are human concerns such as human rights, environmental protection, disaster relief, and development assistance. These organizations provide technical information and expertise that most governments do not have access to [27][28]. Although most definitions consider NGOs to be non-governmental and active in the private sector, a large part of their activities is among local, national, and international governments. Through communication and affiliation, NGOs meet the goals and aspirations of society and are the best agents for providing leadership for social reconstruction in the developing world [29]. Thus, NGOs seek to influence public policy peacefully in a variety of ways. However, the role of NGOs is not to confront public affairs officials. They are also not an opposition force to the government but act as advisers to serve [29]. In practice, this social participation provides useful information for planners and also helps to identify the cause of the challenges [31], In this way, it will be a tool to regulate behaviors and, consequently, the possibility of future planning of social processes by the needs. In the meantime, a scientific review of the current situation may lead to new strategies on how to influence or facilitate government policy change.

Given what has been said in the theoretical foundations, in this study we seek to identify the dimensions of social innovation based on the collaboration between government and NGOs in crises. For this purpose, we use the qualitative method and grounded theory. Our goal is to achieve a paradigm model for social innovation based on these dimensions.

\section{Literature Review}

A review of previous studies shows that very little attention has been paid to social innovation in academic research [32], and this shortcoming is more pronounced in the issue of social innovation based on collaboration between NGOs and government in a crisis. Rollin and Vincent (2007), describe the evolution of the occurrence and formation of social innovation from the emergence of what is known as an innovative project for capacity building, to the achievement of an innovative strategy, and then finding a solution to the problem, and finally, the added value of that innovation. The purpose of innovation in this model is to expand the innovation strategy in the right conditions and places. The model presented by Mulgan et al. (2007), is based on how to meet a need that has not been met. Sometimes needs are obvious, such as hunger, homelessness, or illness. But sometimes, needs are less obvious or recognized. For example, racism or the need to protect against domestic violence. Murray et al. (2010), presented the six-stage cyclical processes of social innovation research. The goal of social innovation in this model is to transform relationships, balance power, and create a whole new approach to a social problem, which can be explained on a large scale. Model Four C Young Social Innovators (2010), is a simple model of social innovation that has been tested and refined by many experts over the past ten years. In this model, individuals decide for themselves what they intend to undertake and directly develop their learning about it to gain a deeper understanding. In teamwork, all people use all their talents to generate ideas and develop an application. At the same time, they work directly with others in the community to improve and receive support for their innovation. They also use creative imagination and thinking to develop an innovative response and create the well-being of society. The goal in this model is to communicate effectively to influence and gain the support of others. According to Hubert (2010), social innovation describes the processes that seek to respond to newly developed social needs and achieve better social outcomes. Assogba (2010), has identified five stages for social innovation and believes that in addition to these innovations need to be accepted by the target community, the success of the social innovation process is in its institutionalization, and this goal will be possible with the intervention of the government system. According to studies by The Young Foundation (2012), social innovations usually start with the idea that may be used experimentally or as a prototype. If it is successful, it will be implemented to maintain this new model in the form of processes, such as new investment or a new policy in the collection. The final step is to implement it on a large scale so that the new approach creates a real effect and becomes part of the norms. Pitt Catsouphes et al. (2012), contrary to the usual models, proposed a seven-step model that begins with the decision to engage in the process of social innovation and leads to the consolidation of the process of social innovation through a linear process. Herrera and Alarilla (2013), categorized the process model of the social innovation framework into five stages. After actively assessing the internal and external environment to identify value chain opportunities for social innovation, ideas are generated and evaluated, and prepared for sample testing and implementation. The main focus of this model is on streamlining and executing applications in all possible areas and locations on a large scale. Norman et al. (2013), based on a useful framework, presented social innovation processes in the form of various, sequential and chain steps that explain the idea from beginning to end. The purpose of this model is to influence social innovation on infrastructures and to subject them to innovative changes to harmonize the appropriate response to demands. With an ecosystem perspective, Hahn and Andor (2013), designed a model of social innovation whose ultimate goal is to bring about systematic and sustainable change. Raffeld et al. (2015), interpret the process of social innovation as a new combination of different ideas and forms of collaboration, in which sustainable institutional contexts are created through the empowerment and participation of vulnerable groups. Dako-Gyeke et al. (2020), see the process of social innovation in health as an innovative tool in hands of universities, agencies, and government institutions, thereby responding to the daily needs and constraints of local people in accessing health services and intervening in the control of disease transmission. In this method, learning is from the inside out. That is to say, it encourages local people to collaborate so that academics and government actors can learn from local people new ways to respond to what may seem like unsolvable problems. This approach encourages the academic community to work with associations, community-based organizations, and local enterprises. According to Castro-Arroyave and Duque-Paz (2020), social innovation in the conceptual health approach is under construction and is largely associated with interdisciplinary, cross-sectoral, and social empowerment concepts. The process of social innovation, while often confused with the entrepreneurial process, is often associated with decisionmakers, academia, and industry. Table 1 summarizes previous studies. 
Table 1

Summary of variables extracted from literature review an

\begin{tabular}{|c|c|c|c|c|c|c|c|c|c|c|}
\hline \multicolumn{11}{|l|}{ Variable } \\
\hline \multicolumn{11}{|l|}{ Source } \\
\hline & $\begin{array}{l}\text { Identifying } \\
\text { a problem } \\
\text { or need }\end{array}$ & $\begin{array}{l}\text { Outbreak } \\
\text { idea, } \\
\text { method, } \\
\text { or } \\
\text { answer }\end{array}$ & $\begin{array}{l}\text { Interest, } \\
\text { decision, or } \\
\text { encouragement } \\
\text { to get involved }\end{array}$ & $\begin{array}{l}\text { Shaping } \\
\text { collaboration } \\
\text { and } \\
\text { partnership }\end{array}$ & $\begin{array}{l}\text { Stimulating } \\
\text { the process } \\
\text { through a } \\
\text { social goal }\end{array}$ & $\begin{array}{l}\text { Testing } \\
\text { of } \\
\text { samples } \\
\text { and } \\
\text { choosing } \\
\text { the right } \\
\text { idea }\end{array}$ & $\begin{array}{l}\text { Providing } \\
\text { infrastructure }\end{array}$ & $\begin{array}{l}\text { Identifying } \\
\text { risk } \\
\text { factors }\end{array}$ & $\begin{array}{l}\text { Running } \\
\text { on a } \\
\text { large } \\
\text { scale }\end{array}$ & $\begin{array}{l}\text { Deploym } \\
\text { and } \\
\text { implem } \epsilon\end{array}$ \\
\hline $\begin{array}{l}\text { Rollin and } \\
\text { Vincent } \\
\text { (2007) }\end{array}$ & & 1 & & & & 1 & 1 & & I & 1 \\
\hline $\begin{array}{l}\text { Mulgan et } \\
\text { al. (2007) }\end{array}$ & 1 & 1 & & & & 1 & & & 1 & \\
\hline $\begin{array}{l}\text { Murray et } \\
\text { al. (2010) }\end{array}$ & 1 & 1 & & & & 1 & & & I & \\
\hline $\begin{array}{l}\text { Young } \\
\text { Social } \\
\text { Innovators } \\
(2010)\end{array}$ & & & 1 & 1 & & & & & & \\
\hline $\begin{array}{l}\text { Hubert } \\
(2010)\end{array}$ & ו & 1 & & & & & & & 1 & 1 \\
\hline $\begin{array}{l}\text { Assogba } \\
(2010)\end{array}$ & & I & I & & I & & & & I & ו \\
\hline $\begin{array}{l}\text { The Young } \\
\text { Foundation } \\
\text { (2012) }\end{array}$ & & I & & & & 1 & & & I & 1 \\
\hline $\begin{array}{l}\text { Pitt } \\
\text { Catsouphes } \\
\text { et al. } \\
(2012)\end{array}$ & & I & I & & & I & I & & & 1 \\
\hline $\begin{array}{l}\text { Herrera and } \\
\text { Alarilla } \\
(2013)\end{array}$ & & & & & & I & & & & 1 \\
\hline $\begin{array}{l}\text { Norman et } \\
\text { al. (2013) }\end{array}$ & & 1 & 1 & & I & I & & & 1 & 1 \\
\hline $\begin{array}{l}\text { Hahn and } \\
\text { Andor } \\
(2013)\end{array}$ & & I & & & & I & & & ו & 1 \\
\hline $\begin{array}{l}\text { Raffeld et } \\
\text { al. (2015) }\end{array}$ & & I & & 1 & & & & & & \\
\hline $\begin{array}{l}\text { Dako-Gyeke } \\
\text { et al. } \\
(2020)\end{array}$ & & I & ) & 1 & & & & & & ו \\
\hline $\begin{array}{l}\text { Castro- } \\
\text { Arroyave } \\
\text { and Duque- } \\
\text { Paz (2020) }\end{array}$ & & & & 1 & & & I & ) & & \\
\hline $\begin{array}{l}\text { Current } \\
\text { article }\end{array}$ & 1 & & & ) & I & & 1 & ) & 1 & 1 \\
\hline
\end{tabular}

\section{Methodology}

The present study is defined to identify the factors and indicators affecting the design of the social innovation model using the collaboration between government and NGOs in a crisis, so in terms of purpose, the research is applied and in terms of method, is qualitative. It also uses the "Grounded Theory" strategy with an inductive approach. The statistical population of the study included health experts working in medical units under the supervision of the Ministry of Health and Medical Education. The mentioned experts are 15 people and have master's and higher degrees and more than 10 years of work experience in the field of health. To extract the effective factors and indicators in designing the social innovation model using the collaboration between government and NGOs, the qualitative data method of the foundation was used, and the results were analyzed using MAXQDA 2020 software. Data collection was done through semi-structured interviews. The researcher tried to analyze and scrutinize the event and phenomenon by using the opinions and knowledge of the most knowledgeable people about the research topic. Figure 1 shows the qualitative stages of the research. 
Given that qualitative research does not have specific tests to confirm validity and validity and reliability depend on the stages of the research and the results obtained; Therefore, the validity of the model is measured by checking by the interviewees as well as the use of more than two coders [33][34]. In this regard, the coding was done by the researcher and then reviewed by social innovation experts. Since the selection of experts for the interview was made by snowball method, the findings were re-examined by 10 of the initial interviewees. Finally, the results indicate the existence of appropriate convergence in the opinions of experts. According to Strauss and Corbin (2008), the following criteria are used as questions to assess the validity of a foundation data research that has been used in this research;

Table 2

Evaluation of the quality of research findings

\begin{tabular}{|c|c|c|}
\hline Criterion & Description & Action \\
\hline Fit & $\begin{array}{l}\text { Are the findings consistent with the experience of professionals? Can } \\
\text { participants see themselves in the story, even if not all the details are } \\
\text { relevant to them? Do the findings show them a sense of reality? Do } \\
\text { participants and professionals react emotionally to the findings? }\end{array}$ & $\begin{array}{l}\text { Research findings were shared with } 10 \text { interviewees. } \\
\text { They confirmed it after observing the findings. In } \\
\text { addition, the findings were discussed with social } \\
\text { innovation experts, which resulted in the assurance of } \\
\text { the findings. }\end{array}$ \\
\hline Applicability & $\begin{array}{l}\text { Do the findings provide a new explanation or insight? Can they be used to } \\
\text { change performance or add new content to the knowledge base to } \\
\text { develop policies? }\end{array}$ & $\begin{array}{l}\text { The findings of this study help policymakers and } \\
\text { managers in the field of health and macro-social issues } \\
\text { identify the factors affecting the success of social } \\
\text { innovation based on the collaboration between } \\
\text { government and NGOs in crises and help managers and } \\
\text { policymakers in strategic decisions, especially in a } \\
\text { crisis. }\end{array}$ \\
\hline
\end{tabular}

Concepts Concepts are essential for developing mutual understanding and discussion among professionals; Therefore, the findings are expected to be organized in terms of concepts. As a result, it does not matter how the findings are presented. Rather, it is important that the findings make sense or that they should not be something beyond the mass of interpreted data that makes the reader try to understand it. Of course, concepts must be developed in terms of their characteristics and dimensions to create density and diversity.

Contextualization The findings are incomplete without context. Without context, the reader of concepts of the research is not able to fully understand the events that took place and why certain meanings are attributed to the events.

Logic Is there a logical flow of ideas? Do the findings make sense? Or are there gaps or missing links in logic that confuse the reader? Are the methodological decisions clear enough for the reader to judge whether they are appropriate for data collection and analysis?

Depth While the concepts provide a common language for discussion and structure the findings, depth is a descriptive detail that enhances richness and diversity and takes the findings out of the ordinary. In-depth is the concept that distinguishes between insignificant findings and those that have the potential to change policy and practice.

Variation Is there diversity in the findings? That is, are there examples of items that do not fit the pattern or have differences in specific dimensions or features?

Creativity

Are the findings presented creatively and innovatively? Does this research say anything new? Or put old ideas together in new ways?

Sensitivity

Has the researcher been sensitive to participants and data? Were the data collection questions obtained through analysis? Or were the concepts and questions created before the data was collected?

Evidence of memos

Because the researcher cannot recall all the insights, questions, and depth of thought that go through the analysis, notes are one of the most essential steps. Notes should grow in depth and degree of abstraction as research progresses.
Attempts were made to make the research findings meaningful and to develop them into meaningful main and sub-categories; Therefore, the research findings were shared with 10 interviewees. After observing the findings, they stated that the findings were understandable to them. In addition, the findings were discussed with social innovation experts, which resulted in the assurance of the findings.

To this end, an attempt was made to express the research findings in the field that leads to the success of social innovation based on the collaboration between government and NGOs in a crisis.

To this end, efforts were made to make the research findings have a tangible meaning and the methodological decisions to be completely clear so that the reader can judge whether they are suitable for data collection and analysis.

To this end, an attempt was made that the concepts in this study provide a common language for discussion and give an organized structure to the data to provide in-depth findings and, as far as possible, more internal layers in social innovation based on popular participation in the statistical community.

In this study, an attempt was made to refer to social innovation experts to examine new dimensions of the phenomenon that are different from the dominant pattern that emerged in previous findings.

For this purpose, in this research, an attempt was made to present the findings creatively and innovatively. This was achieved through a review of multiple data and their frequent analysis.

In this study, an attempt was made to use a semistructured interview. So, several questions were asked from the beginning, but during the interview and data collection process, new questions were formed and guided the research.

In this research, an attempt was made to write down points that come to the researcher's mind during the interview process. Also, during the analysis process, important points were entered in the notes section of MAXQDA software.

\section{Introducing The Best Practice "every Home Is A Health Base"}

Paying attention to the best practice in policymaking and related research is an essential point that can give more credibility to the results [35]. Therefore, in this research, the national program "Every Home is a Health Base" as a best practice [36], in the field of information and epidemic control was reviewed and modeled. In this project, the management and control of the Covid-19 epidemic were designed and implemented jointly by the Ministry of Health \& Medical Education and the NGOs in a neighborhood and family-centered manner. In the first half of 2020, a senior official from the Ministry of Health \& Medical 
Education launched the idea of the "Every Home is a Health Base" program with the primary goal of attracting public and NGO participation in efforts to control the epidemic. In this project, the method of attracting public participation has been through the selection of a health ambassador for each household, and a neighborhood health interface for every 40 household ambassadors, (ambassadors were from NGOs) focusing on mobilizing neighborhood facilities, on improving social (including health), the economic and cultural status of the community. In this regard, using all the capacities of the country, especially the NGOs, to help the Ministry of Health, which has been in control of the epidemic, by the implementation of the plan to hand over controlling Covid-19, to the people of the neighborhoods by using the coordination and management of active units in the neighborhoods (health base in urban areas / rural health house and mobilizing neighborhoods) and extensive participation of other stakeholders such as Red Crescent and NGOs, was used as a suitable strategy to control the disease at the neighborhood level. This project is a clear example of attracting public participation, cross-sectoral coordination, planning based on the needs of neighborhoods (Bottom-up Planning), and optimal use of the potential of the country's health care network system. A very important task of planning and coordination to educate the public to improve the knowledge and skills of the people to face Covid-19, relying on the program "Every home is a health base", and taking advantage of all local facilities and extensive participation of mobilization NGOs and people, was entrusted to the Central Committee under the responsibility of the University of Medical Sciences. This was done through support, care, and monitoring teams [37].

\section{Results}

In the first stage, to collect data, first, 68 references, including articles and books related to social innovation, were examined. For this purpose, to access the documents, researches entitled "Social Innovation" were first extracted from valid databases. They were then screened several times. Finally, the authors reached a theoretical consensus, and the final documents were selected. The indicators extracted from these documents are given in the literature review section and Table 1. In the second stage, to extract the indicators of the social innovation model based on the collaboration between government and NGOs in the crisis of Covid-19, the grounded theory and semi-structured interviews with 15 health experts, which were determined by the snowball method, were used. These experts had master's and higher education and had an average of 17 years of experience working in medical units under the supervision of the Ministry of Health and Medical Education, and had responsibility in the national program "Every Home Is a Health Base" to control and manage, the Covid-19 epidemic, in a neighborhood and family-centered manner. From the tenth person onwards, the data analysis did not lead to the discovery of new concepts and categories. However, to ensure theoretical saturation, five more interviews were conducted, and the data related to them were analyzed. The coding steps in grounded theory include three steps of open, axial, and selective coding [33]. Each of these steps is described below.

Step 1: Open Coding; This step of the grounded theory method is performed immediately after the first interview; In other words, after each interview, the researcher begins to find concepts and select appropriate labels for them and combine related concepts. According to Strauss and Corbin (1998), the steps of open coding are:

1. 1. Analysis and coding: At this stage, the researcher must pay attention to coding and all events. Many codes may be extracted from an interview or text, but when the data is reviewed, new coding counts and final codes are identified.

2. 2. Discover the categories: At this stage, the concepts themselves are classified based on similar topics, which is called categorization (theme building). The titles we assign to categories are more abstract than the concepts that make up that category. Classes have high conceptual power because they can gather concepts around their axis. Introductory titles were chosen mainly by the researcher himself and tried to have the most relevance and consistency with the data it represents. Another important source is the terms used by research participants and can be used by the researcher.

3. 3. Description of categories according to their characteristics: To make the categories clearer, their properties are stated in the next step.

4. 4. Open coding table: Includes a table of primary codes extracted from the interviews and a table of categories extracted from the concepts (Tables 3 to 8 ) along with their secondary codes.

Step 2: Axial coding; In the second stage of coding, which is called axial coding, the researcher selects one of the categories as the axial category and explores it as the axial phenomenon in the center of the process and determines the relationship of the other categories with it. The following five headings explain the connection between other categories and the axial category [34].

1. Axial phenomenon: which is also called the main category, is a phenomenon that is the main axis of research. In this research, social innovation based on the collaboration between government and NGOs in crises is the main category, and the effectiveness of NGOs collaboration in the implementation of the social innovation plan is the axial code that was extracted from open codes based on the inductive approach, is presented in Table 3.

Table 3

Coding based on Strauss and Corbin approach to the axial phenomenon (axial category)

\begin{tabular}{|c|c|c|c|}
\hline Macro Category & Axis Code & Open Codes & $\begin{array}{l}\text { Sample } \\
\text { Interview Code }\end{array}$ \\
\hline $\begin{array}{l}\text { Social innovation } \\
\text { based on the } \\
\text { collaboration } \\
\text { between government } \\
\text { and NGOs in a crisis }\end{array}$ & $\begin{array}{l}\text { The effectiveness of } \\
\text { NGOs collaboration in } \\
\text { the implementation of } \\
\text { the social innovation } \\
\text { plan }\end{array}$ & $\begin{array}{l}\text { The executive capacity of NGOs, motivation, and commitment of NGOs, education, } \\
\text { and experience of NGOs' members, ability to communicate effectively by NGOs, } \\
\text { number of NGOs, having a spirit of sacrifice and self-dedication of NGOs' members, } \\
\text { developing and promoting a culture of participation in society }\end{array}$ & $\begin{array}{l}\text { P1, P2, P3, P4, } \\
\text { P5, P6, P7, P8, } \\
\text { P9, P10, P11, } \\
\text { P12, P13, P14, } \\
\text { P15 }\end{array}$ \\
\hline
\end{tabular}

2. Causal conditions: These conditions cause the formation of axial phenomenon or category. These conditions are a set of categories and their characteristics that affect the axial category. In this research, the micro category based on open codes of interviews and documents (in the form of Table 4) is including investment, to attract NGOs' collaboration in the implementation of the social innovation plan. 


\begin{tabular}{|c|c|c|c|}
\hline Macro Category & Axis Code & Open Codes & $\begin{array}{l}\text { Sample } \\
\text { Interview } \\
\text { Code }\end{array}$ \\
\hline $\begin{array}{l}\text { Social innovation } \\
\text { based on the } \\
\text { collaboration } \\
\text { between } \\
\text { government and } \\
\text { NGOs in a crisis }\end{array}$ & $\begin{array}{l}\text { investment, to attract } \\
\text { NGOs collaboration } \\
\text { in the implementation } \\
\text { of the social } \\
\text { innovation plan }\end{array}$ & $\begin{array}{l}\text { Government fiscal policies in support of NGOs collaboration, the amount of investment in } \\
\text { the social innovation plan, the continuation of investment in the social innovation plan } \\
\text { during the crisis, financial support in the form of incentive packages, educational support } \\
\text { based on experts in the field, support for research projects on social innovation in the crisis }\end{array}$ & $\begin{array}{l}\text { P2, P3, P4, } \\
\text { P6, P8, P9, } \\
\text { P10, P11, } \\
\text { P12, P13, } \\
\text { P14, P15 }\end{array}$ \\
\hline
\end{tabular}

3. Strategies: 1. Express purposeful behaviors, realities, and interactions that are achieved under the influence of intervening conditions and the prevailing context. in this study, the ability to manage the implementation of the social innovation plan and the ability to network are two micro categories that were identified by decoding. The strategies are presented in Table 5.

Table 5

Coding based on Strauss and Corbin approach to strategies

\begin{tabular}{|c|c|c|c|}
\hline Macro Category & Axis Code & Open Codes & $\begin{array}{l}\text { Sample } \\
\text { Interview Code }\end{array}$ \\
\hline \multirow[t]{2}{*}{$\begin{array}{l}\text { Social innovation based } \\
\text { on the collaboration } \\
\text { between government and } \\
\text { NGOs in a crisis }\end{array}$} & $\begin{array}{l}\text { Ability to manage } \\
\text { the } \\
\text { implementation of } \\
\text { the social } \\
\text { innovation plan }\end{array}$ & $\begin{array}{l}\text { Ability to plan project implementation, ability to budget and allocate project funding, } \\
\text { ability to evaluate project effectiveness, ability to control and monitor project } \\
\text { implementation, identify corrective actions, ability to act quickly and promptly when } \\
\text { risks and opportunities arise }\end{array}$ & $\begin{array}{l}\text { P1, P2, P3, P4, } \\
\text { P5, P6, P7, P9, } \\
\text { P10, P11, P12, } \\
\text { P13, P14 }\end{array}$ \\
\hline & Ability to network & $\begin{array}{l}\text { Attract involvement of organizations effective in project implementation, knowledge } \\
\text { transfer and sharing, knowledge networking, support management, and project } \\
\text { implementation }\end{array}$ & $\begin{array}{l}\text { P1, P2, P4, P5, } \\
\text { P6, P8, P9, } \\
\text { P10, P11, P12, } \\
\text { P13, P15 }\end{array}$ \\
\hline
\end{tabular}

4. Ruling context or contextual conditions: The specific conditions that affect strategies are called contexts, and it is difficult to distinguish them from causal conditions. These conditions include a set of concepts, categories, or contextual variables; in contrast, causal conditions are a set of active variables. Sometimes highly related variables are classified under causal conditions and less relevant variables are classified under the prevailing context. In this research, contextual factors include two micro categories of ability to policymaking overall social innovation plan and providing the necessary cultural and educational infrastructure.

Table 6

Coding based on the approach of Strauss and Corbin on contextual conditions

\begin{tabular}{|lll|l|}
\hline Macro Category & Axis Code & Open Codes & $\begin{array}{c}\text { Sample } \\
\text { Interview Code }\end{array}$ \\
\hline $\begin{array}{l}\text { Social innovation } \\
\text { based on the } \\
\text { collaboration } \\
\text { between government } \\
\text { and NGOs in a crisis }\end{array}$ & $\begin{array}{l}\text { Ability to } \\
\text { policymaking } \\
\text { overall social } \\
\text { innovation } \\
\text { plan }\end{array}$ & $\begin{array}{l}\text { Ability to identify crisis features and characteristics, Ability to identify possible solutions to } \\
\text { crisis management, Ability to select optimal solutions, Ability to organize for implementation, } \\
\text { identify risks and opportunities for project implementation, Ability to define project } \\
\text { performance evaluation indicators }\end{array}$ & $\begin{array}{l}\text { P1, P2, P3, P4, P6, P7, P8, } \\
\text { P5, P10, P11, } \\
\text { P12, P13, P14, } \\
\text { P15 }\end{array}$ \\
\hline $\begin{array}{l}\text { Providing the } \\
\text { necessary } \\
\text { cultural and } \\
\text { educational } \\
\text { infrastructure }\end{array}$ & $\begin{array}{l}\text { Public awareness (media infrastructure including mass media and cyberspace, educational } \\
\text { packages, local advertising), development of educational topics in the curriculum of primary } \\
\text { and secondary schools, using the public acceptance of influential people in different strata } \\
\text { and regions to spread the culture of participation in the community }\end{array}$ & $\begin{array}{l}\text { P1, P2, P3, P4, P7, P8, P9, } \\
\text { P10, P11, P12, } \\
\text { P13, P14, P15 }\end{array}$ \\
\hline
\end{tabular}

5. Intervening conditions: There are situations in which strategies are affected. These conditions constitute a set of mediating variables. Intervening conditions are structural conditions that facilitate or limit the intervention of other factors and have a causal and general nature. Based on the open codes, the micro category in this step includes the existence of capable legal organizations to solve the executive problems of the plan and facilitate coordination. The coding for the intervention conditions is given in Table 7.

Table 7

Coding based on Strauss and Corbin's approach to intervening conditions

\begin{tabular}{|c|c|c|c|}
\hline Macro Category & Axis Code & Open Codes & $\begin{array}{l}\text { Sample } \\
\text { Interview Code }\end{array}$ \\
\hline $\begin{array}{l}\text { Social innovation based on } \\
\text { the collaboration between } \\
\text { government and NGOs in a } \\
\text { crisis }\end{array}$ & $\begin{array}{l}\text { Existence of capable legal } \\
\text { organizations to solve the } \\
\text { executive problems of the plan and } \\
\text { facilitate coordination }\end{array}$ & $\begin{array}{l}\text { Facilitating the provision of necessary budget and financial } \\
\text { resources, involving other organizations and institutions to solve } \\
\text { unforeseen problems of the project, facilitating access to support } \\
\text { resources }\end{array}$ & $\begin{array}{l}\text { P2, P3, P4, P6, } \\
\text { P7, P8, P9, } \\
\text { P10, P11, P12, } \\
\text { P13, P14 }\end{array}$ \\
\hline
\end{tabular}

6. Consequences: Some categories represent the results and consequences that result from the adoption of strategies. This coding method, which is called the "paradigm model" of axial coding, has been proposed by Strauss and Corbin, and is called axial because the coding is done around the "axis" of a category. The micro category in this section obtained from open coding includes controlling, containing, and reducing the effects of the crisis. The coding of the consequences is given in Table 8. 
Table 8

Coding based on Strauss and Corbin's approach to consequences

\begin{tabular}{|c|c|c|c|}
\hline Macro Category & Axis Code & Open Codes & $\begin{array}{l}\text { Sample Interview } \\
\text { Code }\end{array}$ \\
\hline $\begin{array}{l}\text { Social innovation based } \\
\text { on the collaboration } \\
\text { between government } \\
\text { and NGOs in a crisis }\end{array}$ & $\begin{array}{l}\text { Controlling, } \\
\text { containing, and } \\
\text { reducing the } \\
\text { effects of the } \\
\text { crisis }\end{array}$ & $\begin{array}{l}\text { Measuring the level of acceptance and public cooperation with the implementers of } \\
\text { the project during the implementation, measuring the statistics of infected patients } \\
\text { during the implementation, reducing the death rate by informing the necessary } \\
\text { measures in case of infection }\end{array}$ & $\begin{array}{l}\text { P1, P2, P3, P4, } \\
\text { P5, P6, P7, P8, } \\
\text { P9, P10, P11, } \\
\text { P12, P13, P14, } \\
\text { P15 }\end{array}$ \\
\hline
\end{tabular}

Finally, at this stage of the qualitative data results, the axial coding paradigm is developed. Figure 2 shows the extracted axial coding paradigm.

Step 3: Selective coding; Strauss and Corbin (1998) describe selective coding with open and axial coding as follows: In open coding, the analyst creates categories and their properties and then tries to determine how categories change during specified dimensions. In axial coding, categories are systematically improved and linked to subcategories. They are not yet the main categories that will eventually be integrated to form a larger theoretical arrangement so that the research results take the form of a theory. Selective coding is the process of integrating and improving categories [38]. At this stage of coding, the grounded theorist writes a theory of the relationships between the categories in the axial coding model. At a basic level, this theory provides an abstract description of the process being studied in research. The process of integrating and improving is theory into selective coding [38], through techniques such as storyline writing that connects categories, and the process of classifying is through personal notes on theoretical ideas. In one storyline, the researcher examines how specific factors affect the phenomenon and lead to the use of specific strategies with specific outputs [39]. In other words, selective coding takes the findings of previous coding steps, selects the axial category, systematically relates it to other categories, proves those relationships, and Completes categories that need further improvement and development; Therefore, the central category is a very important part of integrating and improving categories [40]. In this research, for the dimension of integration and improvement of categories, we achieved one selected code of the effectiveness of NGOs' collaboration in the implementation of the social innovation plan. Table 9 shows the identified codes and Fig. 3 shows the frequency of categories.

Table 9

Identified codes related to social innovation based on the collaboration between government and NGOs in a crisis

\begin{tabular}{|c|c|c|}
\hline Selective code & Axis Code & Open Codes \\
\hline \multirow{3}{*}{$\begin{array}{l}\text { Social innovation } \\
\text { based on the } \\
\text { collaboration } \\
\text { between } \\
\text { government and } \\
\text { NGOs in a crisis }\end{array}$} & $\begin{array}{l}\text { The effectiveness of } \\
\text { NGOs collaboration in the } \\
\text { implementation of the } \\
\text { social innovation plan }\end{array}$ & $\begin{array}{l}\text { The executive capacity of NGOs (C11), motivation and commitment of NGOs (C12), education and } \\
\text { experience of NGOs' members (C13), ability to communicate effectively by NGOs (C14), number of } \\
\text { NGOs (C15), having a spirit of sacrifice and self-dedication of NGOs' members (C16), developing and } \\
\text { promoting a culture of participation in society (C17) }\end{array}$ \\
\hline & (C1) & \\
\hline & $\begin{array}{l}\text { investment, to attract } \\
\text { NGOs collaboration in the } \\
\text { implementation of the } \\
\text { social innovation plan }\end{array}$ & $\begin{array}{l}\text { Government fiscal policies in support of NGOs collaboration (C21), the amount of investment in the } \\
\text { social innovation plan (C22), the continuation of investment in the social innovation plan during the } \\
\text { crisis (C23), financial support in the form of incentive packages (C24), educational support based on } \\
\text { experts in the field (C25), support for research projects on social innovation in the crisis (C26) }\end{array}$ \\
\hline
\end{tabular}

(C2)

Ability to manage the implementation of the social innovation plan

(C3)

Ability to network

(C4)

Ability to policymaking overall social innovation plan

(C5)

Providing the necessary cultural and educational infrastructure

(C6)

Existence of capable legal organizations to solve the executive problems of the plan and facilitate

coordination

(C7)

Controlling, containing, and reducing the effects of the crisis (C8)
Ability to plan project implementation (C31), ability to budget and allocate project funding, ability to evaluate project effectiveness (C32), ability to control and monitor project implementation (C33), identify corrective actions (C34), ability to act quickly and promptly when risks and opportunities arise (C35)

Attract involvement of organizations effective in project implementation (C41), knowledge transfer and sharing (C42), knowledge networking (C43), support management, and project implementation (C44)

Ability to identify crisis features and characteristics (C51), Ability to identify possible solutions to crisis management (C52), Ability to select optimal solutions (C53), Ability to organize for implementation (C54), identify risks and opportunities for project implementation (C55), Ability to define project performance evaluation indicators (C56)

Public awareness (media infrastructure including mass media and cyberspace (C61), educational packages (C62), local advertising (C63), development of educational topics in the curriculum of primary and secondary schools (C64), using the public acceptance of influential people in different strata and regions to spread the culture of participation in the community (C65)

Facilitating the provision of necessary budget and financial resources(C71), involving other organizations and institutions to solve unforeseen problems of the project (C72), facilitating access to support resources (C73)

Measuring the level of acceptance and public cooperation with the implementers of the project during the implementation (C81), measuring the statistics of infected patients during the implementation (C82), reducing the death rate by informing the necessary measures in case of infection (C83) 


\section{Discussion And Conclusion}

Lessons learned from the widespread Covid-19 crisis have shown the world that the current economic and social structures are not efficient enough to respond quickly and effectively to such conditions and need to be fundamentally revised and transformed. To this end, the post-Covid world should use a redistributive framework and surveillance systems as the basis for development rather than development by focusing on economic growth [41]. In this regard, one of the categories that has grown after the emergence of this global challenge is social innovation, and the necessity and importance of having models of social innovation that are operational and effective in times of crisis were increasingly raised as an efficient solution. The term innovation has become a key concept among policymakers around the world due to its widespread use, adaptability, and direct connection to new, creative, and positive ideas [42][43][44][45]. Previous research shows that the concept of innovation through "learning" is attractive to policymakers for a better understanding of uncertain future challenges and the possibility of "easy" planning [45]. In social innovation, policy projects are used as a tool to align policy issues with local and community needs [46]. In the present study, to identify the model of social innovation based on popular participation in a crisis, the theoretical foundations were studied, and field studies were conducted by identifying relevant categories and codes, not only to assist policymakers and managers in macro-strategic decisions but also to create a model that can be used for possible future crises. The results of this study proved that social innovation is a concept with a much broader application of local partnerships to meet the needs in small areas and, this concept can be used effectively at the national level with appropriate speed and agility. It is worth mentioning that this model has several applications, including the development of evidence for a cognitive and multidimensional approach to community empowerment and, consequently, the formation of social innovations. In this research, in the first step, semi-structured interviews were conducted based on the six sections of the grounded theory. Then, based on the analysis of qualitative findings in three stages of open, axial, and selective coding, six categories of causal (Investment, to attract NGOs collaboration in the implementation of the social innovation plan), axial (The effectiveness of NGOs collaboration in the implementation of the social innovation plan), strategies (Ability to manage the implementation of the social innovation plan and Ability to network), intervening (Existence of capable legal organizations to solve the executive problems of the plan and facilitate coordination), contextual (Ability to overall policymaking social innovation plan and Providing the necessary cultural and educational infrastructure) and consequences (Controlling, containing and reducing the effects of the crisis) were identified. The results of the present study are in line with the findings of the research of Rollin and Vincent (2007), Mulgan et al. (2007), Murray et al. (2010), Young Social Innovators (2010), Hubert (2010), Assogba (2010), The Young Foundation (2012), Pitt Catsouphes et al. (2012), Herrera and Alarilla (2013), Norman et al. (2013), Hahn and Andor (2013), Raffeld et al. (2015), Dako-Gyeke et al. (2020) and CastroArroyave and Duque-Paz (2020). The research findings indicate that the effectiveness of NGOs collaboration in the implementing of the social innovation plan, Ability to policymaking overall social innovation plan, and Control, contain and reduce the effects of the crisis are the most critical factors in social innovation based on the collaboration between government and NGOs. The results of this study provide the basis for the development of social innovations based on the collaboration between government and NGOs that leads to sustainable development in communities.

Based on the research results, it is suggested:

- Support laws should be enacted by the legislative authorities to strengthen and facilitate the performance of NGOs.

- Institutions should be established by the government to facilitate communication with NGOs.

- In the context of other crises with a more limited scope (such as earthquakes and floods, etc.), should be focused on how to strengthen and organize and integrate NGOs and government centers.

- For the participation process to be sustainable, other stakeholders and investors, such as private companies and academic associations, should be identified, and their opinion can be attracted for participation.

- To increase the effectiveness of social participation, it is necessary to align the policies of other executive bodies with the goals of NGOs.

In this research, the model was designed with a qualitative approach. In future research, quantitative methods can be used by other researchers. Social innovations in a crisis can also be explored for Ngos' cooperation at the transnational level with international institutions.

\section{Declarations}

\section{- Ethics approval and consent to participate}

Not applicable

\section{- Consent for publication}

Not applicable

\section{- Availability of data and materials}

The datasets used and analyzed during the current study are available from the corresponding author on reasonable request.

\section{- Competing interests}

The authors declare that they have no competing interests

\section{- Funding}

The authors declare that there is no funding for this research 


\section{- Authors' contributions}

M.Moeenian did the interviews and with M.Ghazavi wrote the manuscript. A.Khamseh supervised and lead the discussion of the paper. And they all together worked on the data and findings to design a social innovation model. All authors read and approved the final manuscript.

\section{- Acknowledgments}

Not applicable

\section{References}

1. OECD. Social Entrepreneurship and Social Innovation. in: SMEs, Entrepreneurship and Innovation; 2010.

2. Osburg T, Schmid peter. Social Innovation. Que Vadis? Tilburg School of Social and Behavioral Sciences; 2010.

3. Rehfeld D, Terstriep J, Welchhoff J, Alijani Sh. (2015). Comparative report on social innovation framework". SIMPACT Project Report. Report \#D1.1. available on: http://www.simpactproject. eu/publications/reports/SIMPACT_D1_1_final.pdf.

4. Dietrich M, Znotka M, Guthor H, Hilfinger F. Instrumental and non-instrumental factors of social innovation adoption. Voluntas: International Journal of Voluntary Nonprofit Organizations. 2016;27(4):1950-78.

5. Avelino F, Wittmayer JM, Pel B, Weaver P, Dumitru A, Haxeltine A,.. . O'Riordan, T. (2019). Transformative social innovation and (dis)empowerment. Technological Forecasting and Social Change, 145, 195-206.

6. Phillis JA Jr, Deiglmeier K, Miller DT. (2008). "Rediscovering social innovation, in Stanford Social Innovation Review”. 6 \& 4 Stanford.

7. Edwards-Schachter ME, Matti CE, Alcántara E. Fostering Quality of Life through Social Innovation: A Living Lab Methodology Study Case. Review of Policy Research. 2012;29:672-92. doi:10.1111/j.1541-1338.2012.00588.x.

8. Murray R, Caulier-Grice; Mulgan G. The Open Book of Social Innovation. the Young Foundation and NESTA; 2010.

9. Norman W, Russell C, Clarke K, Mackin D. Growing Social Innovation in Northern IRELAN. The Young Foundation, RSM McClure Watters and the Building Change Trust; 2013

10. Mulgan G, Tucker S, Ali R, Sanders B. Social Innovation: what it is, why it matters, how it can be accelerated. London: University of Oxford, Young Foundation; 2007

11. The Young Foundation. Social Innovation Overview: A deliverable of the project: "The theoretical, empirical and policy foundations for building social innovation in Europe" (TEPSIE), European Commission - 7thFramework Programme. Brussels: European Commission, DG Research; 2012.

12. Social Innovation eXchange (SIX); Young Foundation (2010). Study on Social Innovation, The Bureau of European Policy Advisors.

13. Herrera Maria Elena; Alarilla Cristina Maria. "Social innovation: Business invention and social solutions". Asian Institute of Management. Avalaible on; 2013.

14. Bepa-Bureau of European Policy Advisers. Empowering people, driving change: Social innovation in the European Union. Luxembourg: Publications Office of the European Union; 2010.

15. Rollin J, Valérie V. (2007). "Acteurs et processus d'innovation sociale au Québec". Québec: Réseau québécois en innovation sociale, consulted on-line: http://www.uquebec.ca/ptc/rqis/sites/www.uquebec.ca.ptc.rqis/files.

16. Assogba Y. (2010). "Théorie systémique de l'action sociale et innovation sociale”. Université du Québec en Outaouais (UQO) and Alliance de recherche université-communauté Innovation sociale et développement des communautés (ARUC-ISDC), consulted on-line http://www.uqo.ca/observer/Bulletin/Fichiers/InnovS.pdf) on 5 April 2011.

17. Hahn J, Andor L. Guide to Social Innovation. European Commission; 2013.

18. Pitt Catsouphes M, de Zengotita L, Bergin S. (2012). "Leading the way: Social Innovation in Massachusetts". Available on: http://www.cmsboston.org/assets/files/12-27_Leading\%20 the\%20way.pdf.

19. Dako-Gyeke P, Amazigo UV, Halpaap B, et al. Social innovation for health: engaging communities to address infectious diseases. Infect Dis Poverty. 2020;9:98. https://doi.org/10.1186/s40249-020-00721-3.

20. Castro-Arroyave DM, Duque-Paz LF. Documentary research on social innovation in health in Latin America. Infect Dis Poverty. $2020 ; 9: 41$. https://doi.org/10.1186/s40249-020-00659-6.

21. Oeij PR, van der Torre W, Vaas F, Dhondt S. Understanding social innovation as an innovation process: Applying the innovation journey model. J Bus Res. 2019;101:243-54.

22. Peters B, Herens M, Brouwers J. Capturing Social Innovations in Agricultural Transformation from the Field: Outcomes of a Write-Shop. Sustainability. 2018;10(12):4727.

23. Ubels H, Haartsen T, Bock B. Social innovation and community-focussed civic initiatives in the context of rural depopulation: For everybody by everybody? Project Ulrum 2034. Journal of Rural Studies; 2019.

24. Bello J, Collins S, Dreischmeier R, Libarikian A. Innovating from necessity: The business-building imperative in the current crisis. McKinsey Digital; 2020. April 16.

25. Lee SM, Trimi S. Convergence innovation in the digital age and in the COVID-19 pandemic crisis. J Bus Res. 2021;123:14-22.

https://doi.org/10.1016/j.jbusres.2020.09.041. 
26. Mercer C. NGOs, civil society and democratization in the developing world: a critical review of the literature. Progress in Development Studies. 2002;2(1):5-22.

27. Teegen H, Doh J, Vachani S. The importance of nongovernmental organizations (NGOs) in global governance and value creation: an international business research agenda. J Int Bus Stud. 2004;35:463-83. https://doi.org/10.1057/palgrave.jibs.8400112.

28. Karns MP "Nongovernmental organization". Encyclopedia Britannica, Date I. https://www.britannica.com/topic/nongovernmental-organization. Accessed 30 May 2021.

29. Ghosh B. (2009), NGOs, Civil Society and Social Reconstruction in Contemporary India. Journal of Developing Societies, 25 (2).

30. Geoffroy V, Alain R. Strategies used by international NGOs to influence public policy. Newsletter $\mathrm{N}^{\circ} 5$ : Urgence rehabilitation development; 2010.

31. Leena A, Leskinen. "Purposes and Challenges of Public Participation in Regional and Local Forestry in Finland" (2004). All UNF Research. Paper 14. https://digitalcommons.usu.edu/unf_research/14.

32. Phillips W, Alexander EA, Lee H. Going it alone won't work! The relational imperative for social innovation in social enterprises. Journal of business ethics. 2019;156(2):315-31.

33. Strauss A, Corbin J. Basics of qualitative research: Techniques and procedures for developing grounded theory. 2nd ed.: Sage Publications, Inc.; 1998.

34. Corbin J, Strauss A. Basics of qualitative research: Techniques and procedures for developing grounded theory. 3rd ed.: Sage Publications, Inc; 2008. https://doi.org/10.4135/9781452230153.

35. Ghazinoory S, Ghazinoori S. Developing Iran's government strategies for strengthening the national system of innovation using SWOT analysis. Science Public Policy. 2006;33:Issue 7, Pages 529-40. https://doi.org/10.3152/147154306781778759.

36. U.S. Department of Health and Human Services. Administration for Children and Families Program Announcement. Federal Register, Vol. 68, No. 131, July 2003.

37. Ministry of Health \& Medical Education, Islamic Republic of Iran. (2020). Preparedness and Response for the Control of COVID-19 in the Islamic Republic of Iran. https://behdasht.gov.ir/\%D9\%85\%D8\%B3\%D8\%AA\%D9\%86\%D8\%AF-\%DA\%A9\%D8\%B1\%D9\%88\%D9\%86\%D8\%A7/Preparedness-and-Responsefor-the-Control-of-COVID\%E2\%80\%9319-in-the-Islamic-Republic-of-Iran\#.

38. Strauss AL. Qualitative analysis for social scientists. Cambridge University Press; 1987. https://doi.org/10.1017/CB09780511557842.

39. Creswell JW. Qualitative inquiry and research design: choosing among five approaches. 3rd ed.: Sage Publications, Inc.; 2005.

40. Lee T, W. Using qualitative methods in organizational research. Thousand Oaks: Sage Publications, Inc.; 2001.

41. Büscher B, Feola G, Fischer A, Fletcher R, Gerber J-F, Harcourt W, Koster M, Schneider M, Scholtens J, Spierenburg M, Walstra V, Wiskerke H. (2021), Planning for a world beyond COVID-19: Five pillars for post-neoliberal development, World Development, Volume 140, 105357, https://doi.org/10.1016/j.worlddev.2020.105357.

42. Osborne SP, Brown L. Innovation, public policy and public services delivery in the UK. The word that would be king? Public Adm. 2011;89(4):1335-50.

43. Ayob N, Teasdale S, Fagan K. How Social Innovation 'Came to Be': Tracing the Evolution of a Contested Concept. Journal of Social Policy. 2016;45(4):635-53. doi:10.1017/S004727941600009X.

44. Edler J, Fagerberg J. Innovation policy: what, why, and how. Oxf Rev Econ Policy. 2017;33(1):2-23.

45. Hammond J, Bailey S, Gore O, Checkland K, Darley S, Mcdonald R, Blakeman T. (2021). The Problem of Success and Failure in Public-private Innovation Partnerships. Journal of Social Policy, 1-21. doi:10.1017/S0047279421000192.

46. Bailey S, Checkland K, Hodgson D, McBride A, Elvey R, Parkin S, Rothwell K, Pierides D. The policy work of piloting: mobilising and managing conflict and ambiguity in the English NHS. 179: Social Science \& Medicine; 2017. pp. 210-7.

\section{Figures}

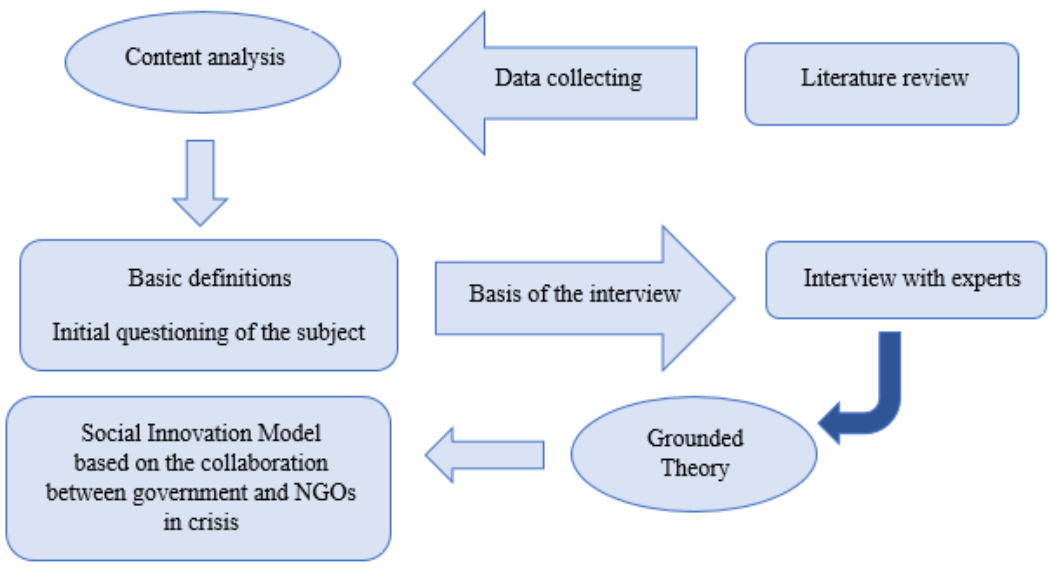

Figure 1

Qualitative research stages using Grounded Theory 


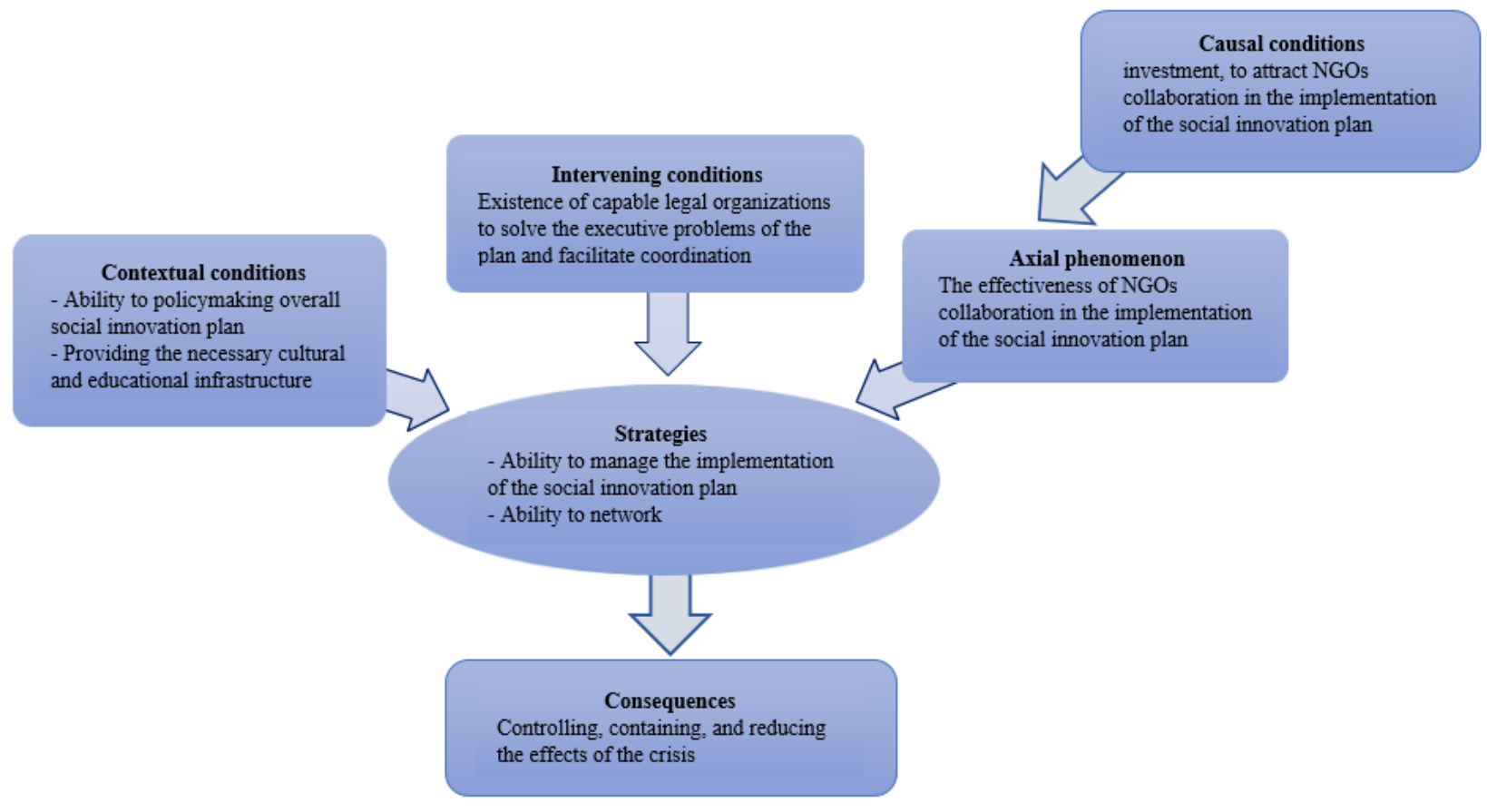

Figure 2

Axial coding designed paradigm model

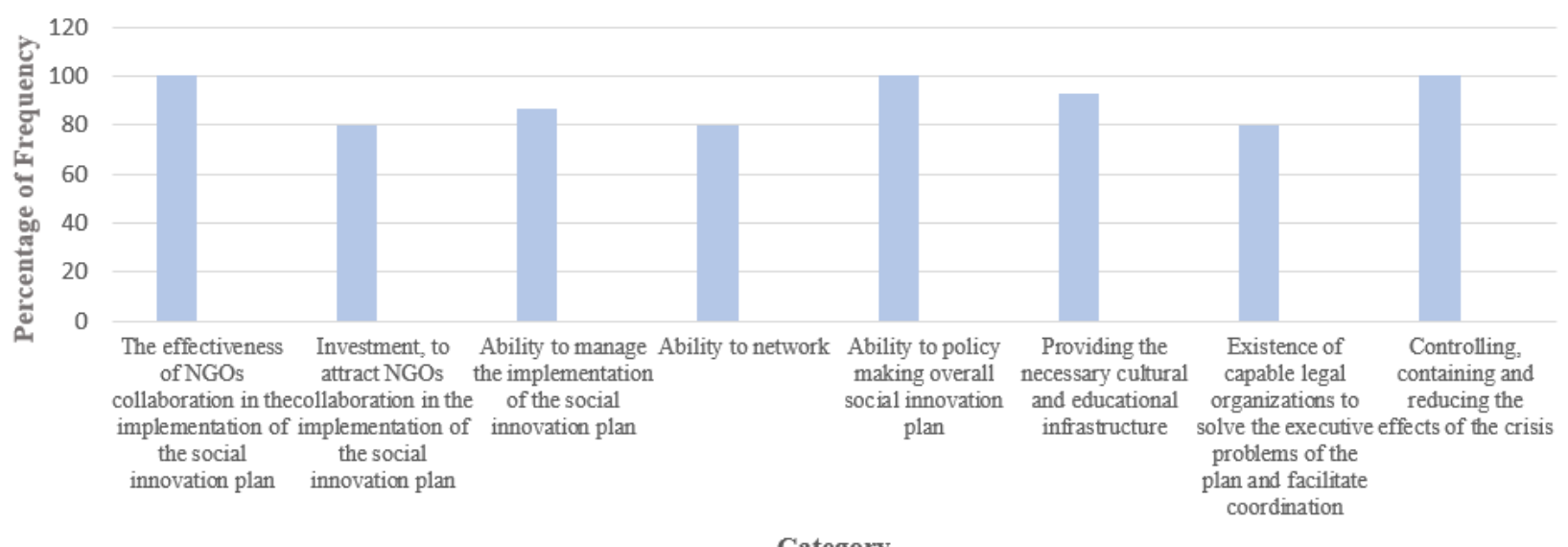

Category

Figure 3

Frequency of social innovation categories based on the collaboration between government and NGOs in a crisis in MAXQDA software 